\title{
FLASH FLOOD MANAGEMENT IN ARID REGION: A CASE STUDY URBAN BANI WASIL VILLAGE, SOHAG GOVERNORATE
}

\author{
Neveen Hamedo*, Marwa Mohamed Aly**, Mohamed Khaled Mostafa***, Samir Zein**** \\ *M.Sc. Student, Faculty of Engineering -Mataria, Helwan University, Cairo, Egypt. \\ ** Associate Professor, Faculty of Engineering-Mataria, Helwan University, Cairo, Egypt. \\ *** Associate Professor, Faculty of Engineering and Technology, badr University, Cairo, Egypt. \\ **** Professor, Faculty of Engineering-Mataria, Helwan University, Cairo, Egypt.
}

Abstract: Flash floods are serious phenomenon that attacks and troubles people in many areas' under-mountain region, so the society should deal with these extreme natural events. This article is showing an example of flash flood modeling to protect the urban bani wasil village from the flash flood risk, so obstacle dam with channel have been used to flash flood mitigation purpose. A design flood wave that used, is for recommence period of 100 years, which estimate by HEC-HMS to be $456,000 \mathrm{~m}^{3}$ total runoff volume. EPA's SWMM software was used for numerical modeling, which includes flood mitigation calculation. Additionally, the cost for dam with channel construction was estimated as early stage for the project.

Keywords: WMS, HEC-HMS, EPA-SWMM, Flash Flood.

\section{1- Introduction}

In the arid and semi-arid region, flash floods occur huge loss of human life and the economy. On the other side, however, rainfall water can use as an important resource of water in arid environments [1]. flash flood is known as a rapid developed flood in just few minutes or hours of rainfall with high intensity on steep slopes with impermeable soils, exposed rocks and poor vegetation [2]. Egypt is on of arid and semi-arid Arabian countries that attack by flash flood, different areas in Egypt face several flood events as Sinai Peninsula, Ambagi, Eastern Desert, Read Sea and Upper Egypt such as Assiut, Sohag, Qena And Aswan [3]. During the last decades between 1972 and 2015 more than 15 destructive flash floods events have occurred, as shown in Table 1. Sohag governorate has a history of destroy flash flood at different center in 2012, 2014, and 2016 at Saqlitah, Dar Al-Salam, Akhmim and Tahta, which flash flood destroy the infrastructure, life, property, and obstructive dams [4]. Mitigation strategies used to vulnerability and 
decrease the risk of flash flood events, which exposure of infrastructure, property and life for hazard [5]. Sohag governorate has 22 natural and industrial torrents in the centers of Dar al-Salam, Akhmim, Saqlaatah, Tahta and Tama, including a new protection dam and an industrial lake in the village of Al-Hajer in the Saqlitah center to exposed flash floods risks [6]. There are two main types of flash flood risk reduction strategies which are structural and non-structural, non-structure has advantage of less cost than structure one [7] [8] [9]. Structure strategies slection depend on some factors as catchment size and flood peak, flood structural strategies include dam, retention dikes, channel and reservoir [10].in this acritical will suggest the mitigation strategy to protect Urban Bani Wasil village, Sohag Governorate is one of the villages located under the foot of mountain. It has a population of 3,975 , with a poverty rate of $77.83 \%$ [11]. Sohag was unfortunate to be confined between two mountains, "the eastern mountain and the western mountain," and most of its villages are located near the two mountains, some of which are located under the foot of the mountain, and some of them fall in the bosom of the mountain [12]. Figure 1. Shown one of the villages located under the foot of mountain. In 2016 flood water covered bani wasel primary school as shown in Figure 2.

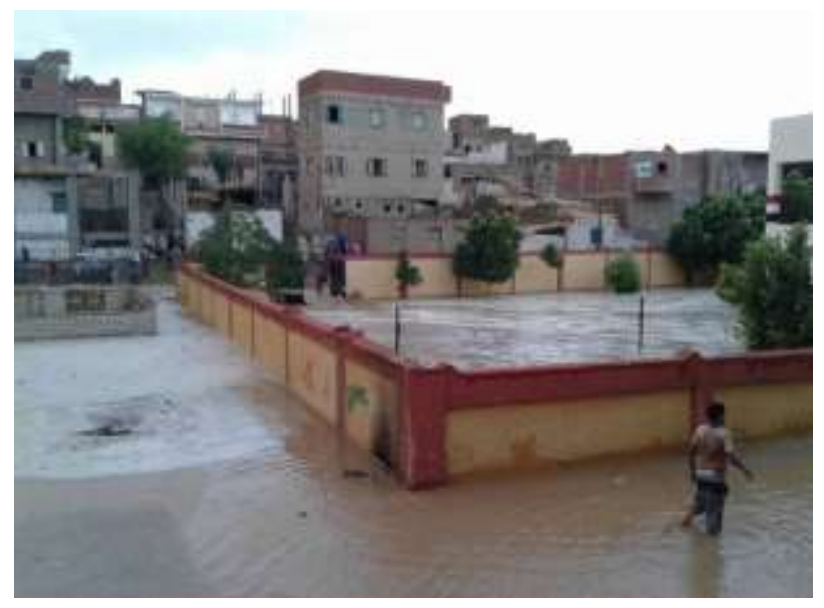

Figure.1 Flood water cover the Bani Wasel

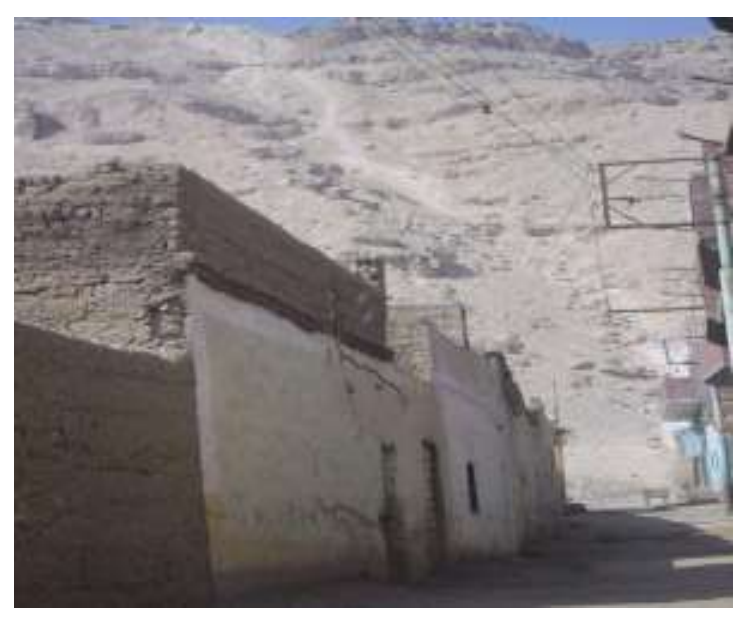

Figure.2 Village located under-mountain primary school 
Table.1 Flash flood main events in Egypt [13]

\begin{tabular}{|c|c|c|}
\hline Date & Effected area & Recorded damages \\
\hline Feb 2015 & Sinai, Red Sea region & Road damages \\
\hline $\begin{array}{l}\text { Mar. and } \\
\text { May. } \\
2014\end{array}$ & $\begin{array}{c}\text { Taba, Sohag, Aswan, Kom } \\
\text { Ombo }\end{array}$ & $\begin{array}{l}\text { Dam failure at sohag, } \\
\text { road damages }\end{array}$ \\
\hline 2013 & South Sinai & 2 death, road damage \\
\hline 2012 & $\begin{array}{l}\text { Wadi Dahab, Catherine } \\
\text { area }\end{array}$ & $\begin{array}{l}\text { Dam failure, destroyed } \\
\text { houses }\end{array}$ \\
\hline Jan. 2010 & $\begin{array}{c}\text { Along the Red Sea Coast, } \\
\text { Aswan, Sinai }\end{array}$ & $\begin{array}{l}12 \text { death, damage } \\
\text { houses and roads }\end{array}$ \\
\hline Oct. 2004 & Wadi Watir & Road damage \\
\hline $\begin{array}{l}\text { May. } \\
1997\end{array}$ & Safaga, El-Qusier & \multirow{3}{*}{$\begin{array}{l}200 \text { death, } \begin{array}{l}\text { destroy } \\
\text { roads, } \\
\text { houses, } \\
\text { vehicles }\end{array} \\
\text { damolished } \\
\end{array}$} \\
\hline $\begin{array}{l}\text { Nov. } \\
1996\end{array}$ & Hurghada, Marsa Alam & \\
\hline $\begin{array}{l}\text { Sep., } \\
\text { Nov. } \\
1994\end{array}$ & $\begin{array}{l}\text { Dahab, Sohag, Qena, } \\
\text { Safaga, El-Qusier }\end{array}$ & \\
\hline $\begin{array}{l}\text { Mar., } \\
\text { Aug. } \\
1991\end{array}$ & Marsa Alam, Wadi Awag & \multirow[t]{2}{*}{ Destroyed houses } \\
\hline Oct. 1990 & $\begin{array}{l}\text { Wadi El-Gemal, Marsa } \\
\text { Alam }\end{array}$ & \\
\hline Jan. 1988 & Wadi Sudr & 5 death \\
\hline Oct. 1987 & South Sinai & 1 death, road damage \\
\hline $\begin{array}{l}\text { May, Oct. } \\
1979\end{array}$ & $\begin{array}{l}\text { Aswan, Kom Ombo, Idfu, } \\
\text { Assiut, } \\
\text { Marsa Alam, ElQusier }\end{array}$ & $\begin{array}{l}23 \text { death, demolished } \\
\text { houses }\end{array}$ \\
\hline Feb. 1975 & Wadi El-Arish & 20 death, road damage \\
\hline 1972 & Giza & $\begin{array}{l}\text { Destroyed houses, } \\
\text { roads, and farms }\end{array}$ \\
\hline
\end{tabular}




\section{2- Case study: Urban Bani Wasel}

Urban Bani Wasil is in east direction of sohag governorate is one of the hamlets of Jallawiya village, which is affiliated to the Saqulta center, Egypt. drop between the latitude of $26^{\circ} 39^{\prime} 57^{\prime \prime} \mathrm{N}$ to $26^{\circ} 40^{\prime} 51^{\prime \prime} \mathrm{N}$ and longitude of $31^{\circ} 40^{\prime} 30^{\prime \prime} \mathrm{E}$ to $31^{\circ} 42^{\prime} 15^{\prime \prime}$ $\mathrm{E}$ as shows in Figure 3.1. The village has total area $23 \mathrm{~km}, 70 \%$ of the total area include agriculture land, and around $30 \%$ of desert land where a habited area which located under the foot of mountain. the study area has an elevation ranging from 95 where the houses located to 65 where agriculture land which include about several houses which about $25 \%$ of the total agricultural land.

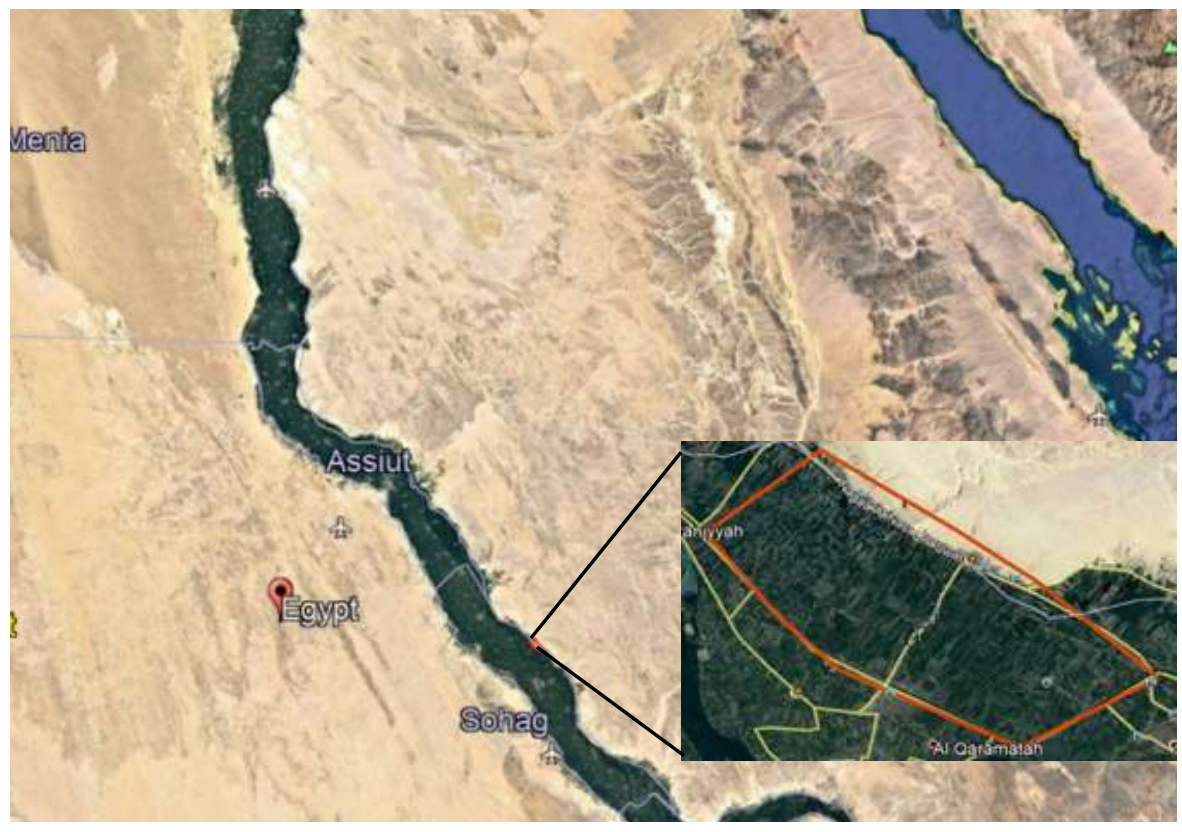

Figure.3 Location of Study Areas.

\section{3- Methodology}

Studying flash flood in watershed is determined by gathering and analyzing meteorological, topographical, and morphological data, however, in many arid and semi-arid regions data is usually limited and incomplete and watersheds are mostly ungauged. A big challenge is to select the proper runoff model which suits the available data. This problem has been tackled by several researchers who have studied 
and analyzed watershed in arid regions to developed appropriate rainfall-runoff models

\subsection{Digital Elevation Models (DEMs) for raw data}

Digital elevation model (DEM) data consist of a sampled array of regularly spaced elevation values referenced horizontally either to a Universal Transverse Mercator (UTM) projection or to a geographic coordinate system. The grid cells are spaced at regular intervals along south to north profiles that are ordered from west to east (USGS, 1998) [14] [15].

\subsection{Virtual Terrain Builder}

The DEM was imported to the VT builder. An interpolation was done for the DEM, so the missing data could be interpolated.

\subsection{Watershed Modelling System (WMS)}

The basins were generated using the Watershed Modelling System (WMS 11.0), which was developed by Aquaveo Corporation. The retrieved processed DEMs were used by the WMS to delineate the watershed into basins and sub-basins. The basins and sub-basin flow direction and accumulated flow were computed. The flow directions were then used to create flow path arc (polyline) for each sub-basin to represent the longest flow path. To run the WMS model, the curve number and the design return period must be estimated. The curve number depends on the soil texture data which was determined by SOIL GRIDS (a system for global digital soil mapping that uses state-of-the-art machine learning methods to map the spatial distribution of soil properties across the globe). The results showed the soil is generally Sandy Clay with gravel. According to USDA-NRCS 1984 method, it was determined that the curve number for the adjacent areas has a Hydrologic Soil Group "D" ((USDA), 1968). Generally, the sub basin areas are exposed to long times of dry season before precipitation events making the soil dry and the moisture content is negligible. On that basis the curve number found to be 88 depending on soil group ((USDA), 1968).

\subsection{Temperature and Rainfall}

The year is climatically divided into two specific parts: cold winter from November to April, and hot summer from May to October. Winter temperatures can sometimes drop to freezing point and the lowest temperature was recorded is 2 degrees Celsius below zero in January 1979. January is considered the coldest month in the year, and the average annual rainfall was recorded at 2, 3 and $6 \mathrm{~mm}$ in some years. As for the summer, the temperature can exceed 50 degrees Celsius in the middle of the day, June 
is the hottest month of the year, as the temperature reaches 45 degrees Celsius. All data from 2014 to 2019 was retrieved from from Tropical Rainfall Measuring Mission (TRMM) which is a satellite related to NASA and the Global Weather data for swat from 1979 to 2014 Table.2 shows the Annual maximum pereciption data from 1979 to 2019.

(https://giovanni.gsfc.nasa.gov/giovanni//, https://globalweather.tamu.edu/)

Table .2 Annual maximum precipitation from 1979 to 2019

\begin{tabular}{|c|c|c|c|c|c|c|c|c|c|}
\hline year & 1979 & 1980 & 1981 & 1982 & 1983 & 1984 & 1985 & 1986 & 1987 \\
\hline $\mathbf{P}$ & 2.41 & 5.95 & 0.23 & 35.7 & 0.3 & 0.5 & 9.7 & 0.15 & 12.0 \\
\hline year & 1988 & 1989 & 1990 & 1991 & 1992 & 1993 & 1994 & 1995 & 1996 \\
\hline $\mathbf{P}$ & 25.0 & 3.0 & 25.6 & 83.0 & 6.0 & 25.0 & 17.0 & 6.5 & 1.0 \\
\hline year & 1997 & 1998 & 1999 & 2000 & 2001 & 2002 & 2003 & 2004 & 2005 \\
\hline $\mathbf{P}$ & 0.26 & 8.0 & 0.99 & 0.3 & 3.0 & 0.8 & 2.4 & 3.5 & 0.5 \\
\hline year & 2006 & 2007 & 2008 & 2009 & 2010 & 2011 & 2012 & 2013 & 2014 \\
\hline $\mathbf{P}$ & 0.7 & 0.65 & 3.0 & 0.1 & 13.0 & 3.0 & 12.5 & 5.0 & 19.0 \\
\cline { 1 - 4 } year & 2015 & 2016 & 2017 & 2018 & 2019 & & &
\end{tabular}

P: Annual Maximum Precipitation (mm)

\subsection{Hyfran-Plus for return period}

Hyfran program was used to estimate the return period for different time periods using different statistical distributions. The Hyfran plus program offers 18 different statistical distributions which are available to fit data sets which are independent, homogenous and stationary. The 18 different statistical distributions were tested to identify the best analysis method, the Akaike information criterion (AIC) test and the chi squared test were made to choose the best distribution method.

\subsection{EPA SWMM}

EPA's Storm Water Management Model (SWMM) is widely used for planning, analysis, and design related to stormwater runoff, combined and sanitary sewers, and other drainage systems. It can be used to evaluate gray infrastructure stormwater control strategies, such as pipes and storm drains, and is a useful tool for creating cost-effective green/gray hybrid stormwater control solutions. SWMM was developed to help support local, state, and national stormwater management objectives to reduce runoff through infiltration and retention and help to reduce discharges that cause impairment of water bodies. SWMM contains a flexible set of hydraulic modeling 
capabilities used to route runoff and external inflows through the drainage system network of pipes, channels, storage/treatment units and diversion structures. It used to design pond, channel and Dam in this study to control rainfall water Depending on the total flow from HEC-HMS and the soil permeability.

\subsection{HEC-RAS}

Hydrological Engineering Center-River Analysis System is a software allows the engineers to perform one-dimensional steady flow, one and two-dimensional hydraulic calculation for full constructed channel and water quality modelling. The computational procedure of HEC-RAS for steady flow depend on the solution of onedimensional energy equation. Energy losses are evaluated by contraction and friction. The momentum equation can be used when the water profile is rapidly varied as hydraulic jumps, hydraulics of bridges, and evaluating profiles at river confluences. It used to design and check the water level in the channel and to design dams.

\section{4- Result}

\subsection{Basin Model WMS}

The WMS produced a delineated watershed $10 \mathrm{~km}^{2}$. Additional control points (1B and 2B) Figure. 3 have been identified to develop a more accurate hydrograph, as well as to have a better understanding of the flash flood flow at each sub-watershed, resulting into two watersheds. The morphology data are summarized in Table 5.1. it explains the lag time which reflect the time between the rain fall occurrence and run off. This is radical factor that is considered for flood alert system and disaster management. From the previous table found the largest basin slop is $0.1138 \mathrm{~m} / \mathrm{m}$, the largest stream slop 0.0503 , and the maximum stream length is approximately $4340 \mathrm{~m}$. 
Table .3 The morphology characteristics of the basin in the study area

\begin{tabular}{ccccccccccc}
\hline $\begin{array}{c}\text { Basin } \\
\text { Name }\end{array}$ & $\begin{array}{c}\text { Area } \\
\left(\mathbf{k m}^{2}\right)\end{array}$ & $\begin{array}{c}\text { Basin } \\
\text { Slop } \\
(\mathbf{m} / \mathbf{m})\end{array}$ & $\begin{array}{c}\text { Max } \\
\text { flow } \\
\text { slop } \\
(\mathbf{m} / \mathbf{m})\end{array}$ & $\begin{array}{c}\text { Max } \\
\text { stream } \\
\text { length } \\
\mathbf{( m )}\end{array}$ & $\begin{array}{c}\text { Max } \\
\text { stream } \\
\mathbf{s l o p} \\
(\mathbf{m} / \mathbf{m})\end{array}$ & $\begin{array}{c}\text { Basin } \\
\text { length } \\
(\mathbf{m})\end{array}$ & $\begin{array}{c}\text { Basin } \\
\text { perimeter } \\
(\mathbf{m})\end{array}$ & $\begin{array}{c}\text { Basin } \\
\text { shape } \\
\text { factor } \\
\left(\mathbf{m i}^{2} / \mathbf{m i}^{\mathbf{2}}\right)\end{array}$ & $\begin{array}{c}\text { Basin } \\
\text { Average } \\
\text { elevation } \\
(\mathbf{m})\end{array}$ & $\begin{array}{c}\text { Lag } \\
\text { time } \\
(\mathbf{h})\end{array}$ \\
\hline 1B & 3.08 & 0.0471 & 0.0159 & 2093 & 0.0140 & 2203 & 9699.27 & 1.58 & 297 & 0.6720 \\
\hline 2B & 7.3 & 0.1138 & 0.0473 & 4340 & 0.0503 & 4352 & 166925.51 & 2.60 & 266 & 0.06941 \\
\hline
\end{tabular}

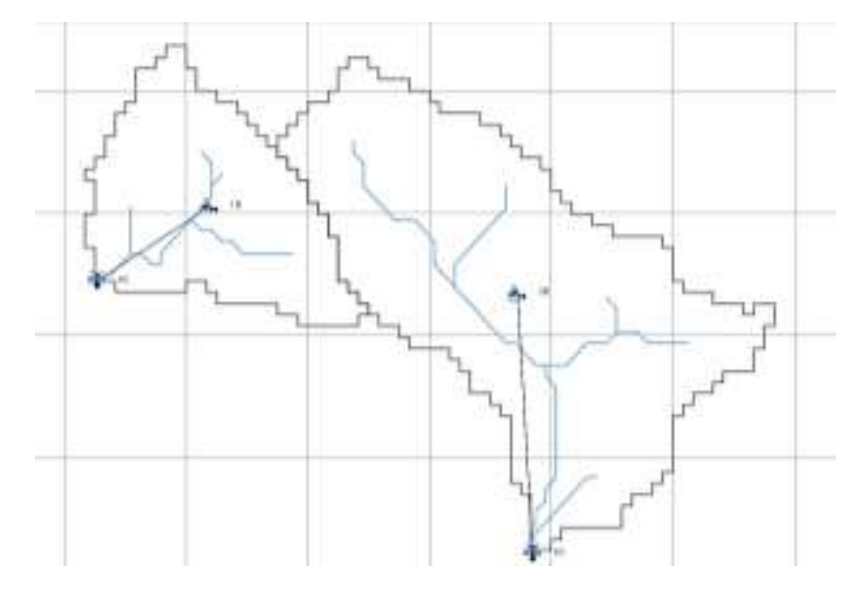

Figure .4 watershed control points

\subsection{Hyfran-Plus for return period}

The Return Period was calculated for the watershed studied using the perception data Table 3.2 in chapter three. Figure 5.2 illustrates the return period versus the rainfall. According to the Akaike Information Criterion (AIC) test, The lowest AIC indicates the best fitting distribution [16] which was found to be gamma distribution for the return period calculation for the studied regions. Upon searching the literature, it was founded that the gamma distribution system is one of the most flood frequently selected for hydrological frequency analysis [17]. The gamma distribution was found to provide the best fit in pervious study in arid $r$ and semi-arid regions for example ( [18] in Saudi Arabia and [19] in Iran). 


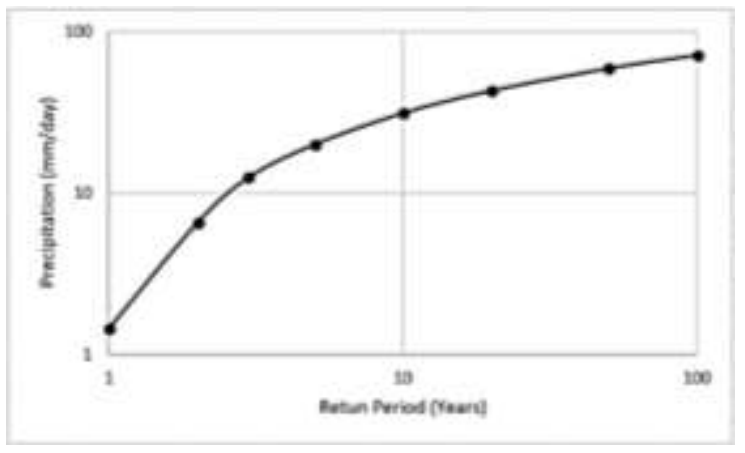

Figure.4 Return period Gamma

\subsection{HEC-HMS}

The hydrographs at different control point of the watershed were retrieved from HECHMS Figure (4.4). These hydropaths helped in determining the maximum amount of water that is expected to reach the village. The total runoff volume that would affect the village can be assumed to be the flow at control point $6 \mathrm{C}$ which is about 91,100 $\mathrm{m}^{3}$ for 50 -years return period and $133000 \mathrm{~m}^{3}$ for 100-years return period,7C about $11,500 \mathrm{~m}^{3}$ for 50 -years and $17,000 \mathrm{~m}^{3}$ and for point $5 \mathrm{C} 12,900 \mathrm{~m}^{3}$ for 50 - years and $19,000 \mathrm{~m}^{3}$ for 100 -years. 

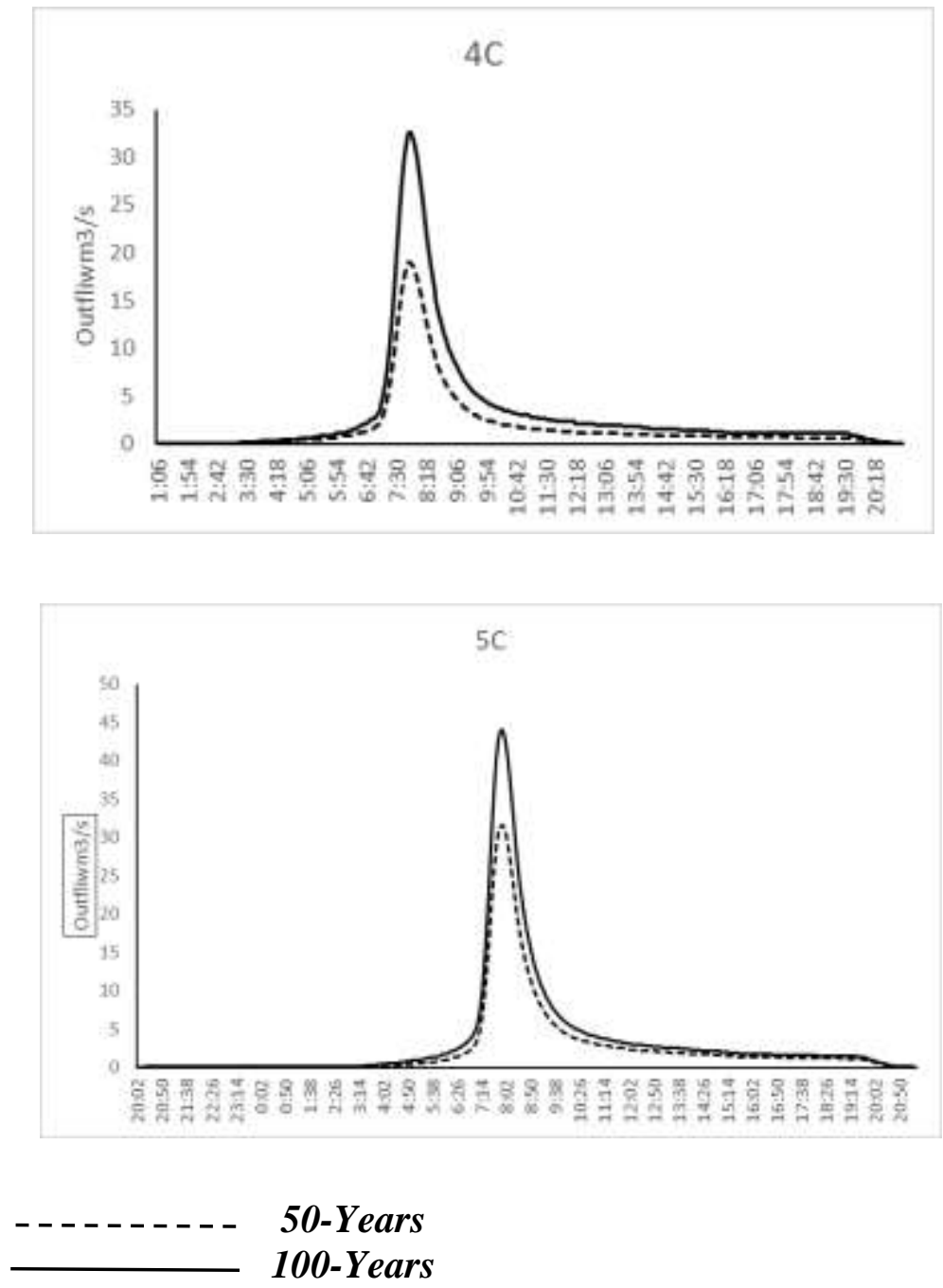

Figure.5 Streamflow vs Time/Date for 50-years and 100-year return periods. 


\subsection{Dam Design}

Flashfloods are one of the most dangerous natural disasters. Flashflood is a problem that affects all countries each year, which cause considerable damage to people's lives and properties [20]. Dam is a structure used for mitigation of flashfloods, so EPA's SWMM will used to design dam, which will be located across the stream. from the result can be done by using small ditch to contact the two streams together as illustrated in Figure.6.

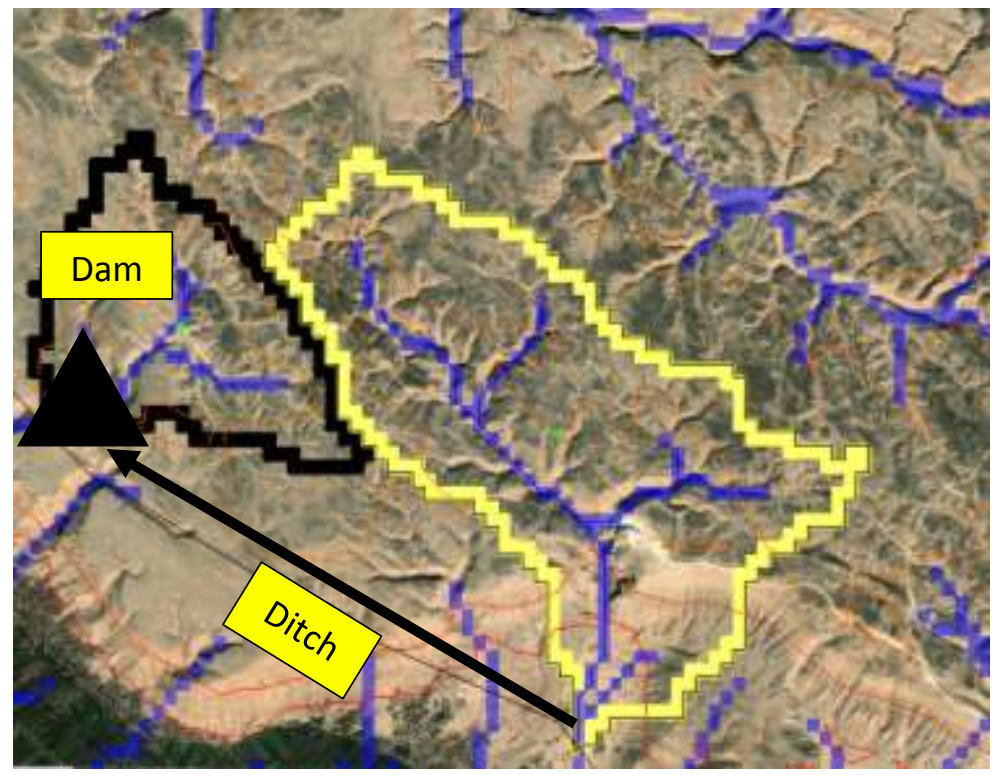

Figure.6 Dam and ditch location

By using google earth image found that the ditch has a location as illustrate in Figure.6 start from 2B to 1B (basin) depending on the land elevation to carry rainfall water from high level $180 \mathrm{~m}$ to low level $110 \mathrm{~m}$ under gravity. The runoff water will increase with time until the storm end. Figure 5.7 illustrate the water depth increase with time until reach to the max depth about $16 \mathrm{~m}$, so the dam crest height assumed to be $18 \mathrm{~m}$. The ditch is a small channel will carry rainfall water from the control point of watershed 2B to the control point of $1 \mathrm{~B}$. The small channel will flow under gravity, ditch dimension selected illustrate in Table.4. 
Table.4 properties of channel cross section.

\begin{tabular}{cc}
\hline Properties & Dimension \\
\cline { 2 - 2 } & Meter \\
\hline depth & 2 \\
Bottom width & 3 \\
Side slop & $1: 1$ \\
Longitudinal slop & $0.019 \mathrm{~m} / \mathrm{m}$ \\
\hline
\end{tabular}

\subsection{Cost Analysis}

Cost estimation to the dam and channel depending on the 100-year return period to the critical case for the quantity of water that will saved behind the dam. A conceptual cost estimation is prepared to assess the feasibility of a project or establish the project's initial budget at the early stages of the project [21].

\subsubsection{Channel Cost Estimation}

To estimate channel total cost, the area cross-section should be calculate using eq 4.1, and wetted parameter important to lining cost estimation that will be calculated from eq 4.2 that illustrate in section four. Table 5.4 illustrate the total cost estimation for channel construction operation.

Table.5 show channel area, perimeter, and lateral area to calculate total cost of channel.

\begin{tabular}{cccc}
\hline Length, $(\mathbf{m})$ & $\begin{array}{c}\text { Area, } \\
\left(\mathbf{m}^{2}\right)\end{array}$ & Perimeter, $(\mathbf{m})$ & Lateral Area, $\left(\mathbf{m}^{2}\right)$ \\
\hline $\mathbf{3 0 0 0}$ & 10 & 8.65 & 8.65 \\
Drilling cost & $\mathbf{2 1 0 , 0 0 0 ~ E G P ~}$ & \\
pitching lining cost & $\mathbf{7 , 7 8 5 , 0 0 0 ~ E G P ~}$ & \\
Total cost & $\mathbf{7 , 9 9 5 , 0 0 0 ~ E G P ~}$ &
\end{tabular}




\subsubsection{Dam Cost Analysis}

Dam cost estimation depended on the volume of dam and the materials used to construct, Table 5.5 have all needing details for calculate the cost as length and area.

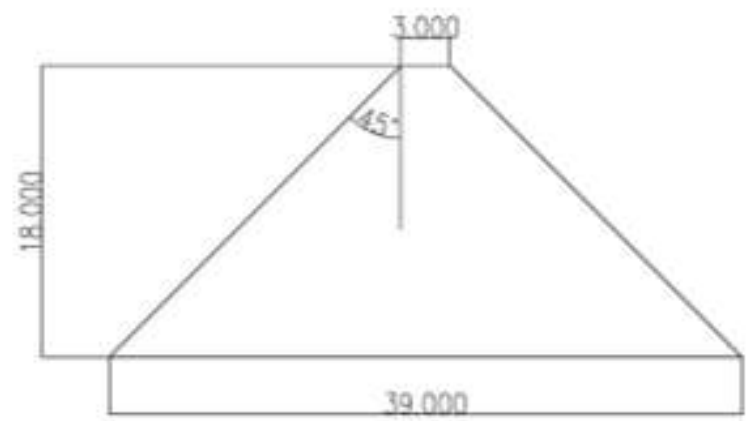

Table 5.5 Dam cost estimation depending on construction material

\begin{tabular}{cccc}
\hline Length, $(\mathbf{m})$ & $\begin{array}{c}\text { Area, } \\
\left(\mathbf{m}^{\mathbf{2}}\right)\end{array}$ & Perimeter, $(\mathbf{m})$ & volume, $\left(\mathbf{m}^{\mathbf{3}}\right)$ \\
\hline $\mathbf{3 0 0}$ & 103 & 59.25 & 25,750 \\
Reinforced concrete cost & $\mathbf{7 2 5} * \mathbf{2 5 7 5 0}$ & & \\
Total cost & $\mathbf{1 8 , 6 6 8 , 7 5 0 ~ E G P ~}$ &
\end{tabular}

Total cost for $($ channel + dam $)=26,663,750$ EGP

\section{Conclusion}


Using channel and dam to protect the the village from the rainfall storm. The channel will take the accumulated rainfall water from the first control point away to the dam location at the second control point the system has a total cost estimation about 26,663,750 EGP

\section{References}

[1] M. a. K. S. a. S. T. ABDEL-FATTAH, "Integrated management of flash flood in wadi system of egypt: Disaster prevention and water harvesting," 2015.

[2] X. Lin, "Flash floods in arid and semi-arid zones," Technical documents in hydrology, 1999.

[3] A. M. Negm, Flash Floods in Egypt, Springer, Cham, 2020.

[4] elwatannews, "Among them is Akhmim ... the most dangerous place in the event of floods in Soha, Khaled Al-Ghwait," https://www.elwatannews.com/, 2020.

[5] S. a. Y. M. a. I. S. a. K. M. a. S. T. Abuzied, "Geospatial risk assessment of flash floods in Nuweiba area, Egypt," Journal of Arid Environments, pp. 54--72, 2016.

[6] youm7, "learn about 22 about natural and industrial outlets of seoul in Sohag Governorate, Mahmoud Maqbool," https://www.youm7.com/, 2019.

[7] N. W. a. A. G. A. a. S. N. a. H. N. N. N. a. T. M. L. Chan, "Integrating structural and non-structural flood management measures for greater effectiveness in flood loss reduction in the Kelantan River Basin, Malaysia," in AWAM International Conference on Civil Engineering, Springer, 2019, pp. 1151--1162.

[8] V.a.P.S. a. K. C. Meyer, "Economic evaluation of structural and non-structural flood risk management measures: examples from the Mulde River," Natural Hazards, vol. 62, pp. 301--324, 2012.

[9] Z. W. Kundzewicz, "Non-structural flood protection and sustainability," Water International, vol. 27, pp. 3--13, 2002.

[10] D. P. a. D. M. B. Patel, "Feasible structural and non-structural measures to minimize effect of flood in Lower Tapi Basin," WSEAS Trans Fluid Mech, vol. 3, pp. 104--121, 
2010.

[11] masrawy, "Tragedies hidden for decades .. "Masrawy" in the villages of Sohag, the poorest and most needy,Ammar Abdel Wahed," https://www.masrawy.com/?Navlogo, 2019.

[12] bloomnews24, "Under the microscope ... the worries and pains of villages in the bosom of the mountain in Sohag," https://bloomnews24.com/, 2020.

[13] G. a. M. M. El Afandi, "Developing an early warning system for flash flood in Egypt: Case study Sinai Peninsula," in Flash Floods in Egypt, Springer, 2020, pp. 45--60.

[14] USGS, "US GeoData Digital Elevation Models," USGS, 1998.

[15] "The Shuttle Radar Topography Mission (SRTM) Collection," 2015.

[16] E. a. E. A. S. a. B. B. Ehsanzadeh, "Frequency analysis incorporating a decision support system for hydroclimatic variables," Journal of Hydrologic Engineering, vol. 15, pp. 869--881, 2010.

[17] S. Yue, "A bivariate gamma distribution for use in multivariate flood frequency analysis," HYDROLOGICAL PROCESSES, vol. 15, p. 1033-1045, 2001.

[18] M. a. A.-M. M. Abdullah, "Climatological study of the southwestern region of Saudi Arabia. I. Rainfall analysis, " Climate Research, vol. 9, pp. 213--223, 1998.

[19] E. a. V. M. a. E. S. S. Sharifi Garmdareh, "Regional flood frequency analysis using support vector regression in arid and semi-arid regions of Iran," Hydrological sciences journal, vol. 63, pp. 426--440, 2018.

[20] V. a. B. N. a. N. A. a. M. D. a. T. V. a. L. J. a. M. V. Badenko, "Ecological aspect of dam design for flood regulation and sustainable urban development," in MATEC Web of Conferences, EDP Sciences, 2016, p. 03003.

[21] H. H. a. E. A. H. a. I. A. H. ElMousalami, "Predicting conceptual cost for field canal improvement projects," Journal of Construction Engineering and Management, $p$. 04018102, 2018.

[22] G. a. M. M. El Afandi, "Developing an early warning system for flash flood in Egypt: 
Samir Zein / Engineering Research Journal 169 (JANAURY 2021) C1- C16

Case study Sinai Peninsula," in Flash Floods in Egypt, Springer, 2020, pp. 45--60. 